\title{
Development of a new dual electrochemical immunosensor for a rapid and sensitive detection of enrofloxacin in meat samples
}

\author{
Chloé AYMARD ${ }^{1,2}$, Hussein KANSO ${ }^{1,2}$, María Jesús SERRANO 3 \\ Rafael PAGÁN ${ }^{3}$, Thierry NOGUER ${ }^{1,2}$, Georges ISTAMBOULIE ${ }^{1,2}$
}

${ }^{1}$ Université de Perpignan Via Domitia, Biocapteurs-Analyse-Environnement, 66860, Perpignan,

France

${ }^{2}$ Laboratoire de Biodiversité et Biotechnologies Microbiennes, USR 3579 Sorbonne Universités

(UPMC) Paris 6 et CNRS Observatoire Océanologique, 66650, Banyuls-sur-Mer, France

${ }^{3}$ Departamento de Producción Animal y Ciencia de los Alimentos, Facultad de Veterinaria, Instituto

Agroalimentario de Aragón-IA2 (Universidad de Zaragoza-CITA), Zaragoza, Spain 


\section{Abstract}

A novel dual electrochemical immunosensor was fabricated for the rapid and sensitive detection of enrofloxacin (EF) antibiotic in meat. Anti-quinolone antibody was immobilized onto screen-printed dual carbon electrodes via carbodiimide coupling. A new electrochemical probe was synthesized by conjugating difloxacin and aminoferrocene, whose oxidation was measured at +0.2 $\mathrm{V}$ vs. $\mathrm{Ag} / \mathrm{AgCl}$ by differential pulse voltammetry. The detection principle was based on the competitive binding of this conjugate and free EF on immobilized antibodies. The proposed immunosensor allowed detection of $\mathrm{EF}$ at concentrations ranging from $0.005 \mu \mathrm{g} \cdot \mathrm{mL}^{-1}$ to 0.01 $\mu \mathrm{g} \cdot \mathrm{mL}^{-1}$ with a detection limit of $0.003 \mu \mathrm{g} \cdot \mathrm{mL}^{-1}$. The immunosensor was stable for at least 1 month at $4^{\circ} \mathrm{C}$ and displayed a good specificity for other fluoroquinolones. The new dual electrode design offered an improved accuracy as one electrode was used as negative control. The efficiency of the sensor and the adequacy of the extraction process were finally validated by detecting EF in different meat samples.

\section{Keywords}

5 Immunosensor, Enrofloxacin (EF), Fluoroquinolones (FQs), Competitive assay, Screen-printed dual carbon electrodes (SPdCEs), Meat analysis 


\section{Introduction}

Fluoroquinolones (FQs) are broad-spectrum synthetic antibiotics which selectively inhibit bacterial enzymes involved in DNA replication of Gram-negative and Gram-positive bacteria (Blondeau, 2004). These antibiotics, especially enrofloxacin (EF), were mainly used in large-scale breeding to prevent or treat animal diseases or to improve livestock growth and productivity (Cháfer-Pericás et al., 2010; Wolfson \& Hooper, 1985). The use of these compounds as growth promoters is banned in European Union since 2006 (Brown et al., 2017; Diana et al., 2020) and they have been recently classified as restricted antibiotics (European Medicines Agency, 2019). Despite these limitations, Diana et al. recently reported that FQs are the most frequently used antimicrobials (Diana et al., 2020). Moreover, they are still considered as valuable polyvalent tools by a wide number of farmers to treat a variety of diseases. The overuse of FQs in animal husbandry or the disrespect of withdrawal periods settled by the manufacturers can result in the accumulation of antibiotic residues in animal-derived food, such as meat. Once consumed by humans, these residues present various health risks such as apparition of allergy and toxic reactions in liver, nervous system and skin (Aronson, 2016). This misuse can also lead to the prevalence of multidrug resistant pathogens, representing a serious public health concern (Alekshun \& Levy, 2007; Tenover, 2006).

In order to avoid these problems and to protect consumers, the use of antibiotics in food animals has been regulated by establishing maximum residue limits for authorized antimicrobials for each species (MRLs, Commission Regulation (EU) No 37/2010). Regarding EF, MRLs are ranging from $100 \mu \mathrm{g} \cdot \mathrm{kg}^{-1}$ to $300 \mu \mathrm{g} \cdot \mathrm{kg}^{-1}$, depending on the animal species and the target tissue. Therefore, the sensitive and effective monitoring of this antibiotic in food samples is crucial.

Various analytical methods have been developed for the detection of EF in animal tissues, and they can be classified into two categories: screening and confirmatory. Screening methods allow the detection of EF at the concentration of interest but they usually correspond to qualitative or semi-quantitative tests. These methods include enzyme-linked immunosorbent assays (Hu et al., 2019; Z. Wang et al., 2014; Zhang et al., 2011), immunochromatographic strip tests (Chen et al., 
2012; Huang et al., 2013), microbiological inhibition tests (Mata et al., 2014; Tumini et al., 2019; Q. Wu et al., 2019) and fluorescent (Dolati et al., 2018; Ha et al., 2016) and colorimetric sensors (Rezende et al., 2019). On the contrary, confirmatory methods, such as capillary electrophoresis (L. Wang et al., 2005; Xu et al., 2015) or high throughput liquid chromatography coupled with mass spectrometry (Panzenhagen et al., 2016), fluorescence (Peris-Vicente et al., 2017) or UV detection (Dunnett et al., 2004) allow both identification and quantification of analytes. However, these methods require sophisticated material, experimented users, as well as complex extraction and clean-up processes.

Despite the progress made in recent years, there is still a strong demand for new strategies to improve sensitivity, simplicity and feasibility of FQs detection methods. In this regard, electrochemical immunosensors have gained special interest as they combine the high specificity of antigen-antibody interaction and the sensitivity, ease of use, and low cost of electrochemical devices. Thereby, many portable and affordable immunosensors have been designed for various applications in clinical diagnosis, environmental monitoring and food analysis (Felix \& Angnes, 2018; Mollarasouli et al., 2019). Screen-printed carbon electrodes appear as attractive transducers for immunosensor development since they can be mass-produced at low cost, they are chemically stable and they can be used as disposable devices (Sharma et al., 2017; Taleat et al., 2014).

Electrochemical immunosensors detecting FQs such as ciprofloxacin (Garifallou et al., 2007; Giroud et al., 2009; Ionescu et al., 2007), ofloxacin (He et al., 2015; Zang et al., 2013), norfloxacin (Liu et al., 2018) and enrofloxacin (Wu et al., 2009) have already been described in literature. The detection methods involved in these immunosensors were mostly based on changes in impedance related to antigen-antibody binding event (Garifallou et al., 2007; Wu et al., 2009), or on voltamperometric detection of a redox molecule generated by an enzyme-labelled secondary antibody (Liu et al., 2018; Zang et al., 2013). However, electrochemical impedance spectroscopy procedures are complex, sensitive to non-specific binding and above all, they are not suitable for the sensitive detection of small molecules (Bahadir \& Sezgintürk, 2016; Kivirand et al., 2019). 
On the other hand, the use of reporter enzymes as antibody labels is expensive and the measurement protocol involves mandatory incubation and washing steps, resulting in increased measurement times (Liu et al., 2018; Zang et al., 2013). For these reasons, a promising strategy consists in the modification of the antigen with an electro-active probe like ferrocene. Ferrocene (dicyclopentadienyl iron) is a well-known redox molecule appreciated for its stability and low toxicity, which displays favorable electrochemical characteristics related to the reversible oxidation of its iron center (Štěpnička, 2008). These properties have been exploited for the development of several sensors where ferrocene derivatives were conjugated with peptides (Martić et al., 2011), proteins (Dechtrirat et al., 2014), oligonucleotides (Nakayama et al., 2002) or sugars (Casas-Solvas et al., 2009). This organometallic molecule was also used to improve antibacterial or antifungal properties of different antibiotics such as ampicillin (Skiba et al., 2012), $\beta$-lactams (Lewandowski et al., 2020), sulfonamides (Chohan, 2009) and FQs like ciprofloxacine (Khor et al., 2011).

Despite the high selectivity and sensitivity of electrochemical immunosensors, inter-electrode variability is often observed due to the inherent differences in surface modification, as well as effect of storage over time. The measurement of a reference signal is therefore required to take into account these variations. Usually employed for the simultaneously detection of biomolecules (Escamilla-Gómez et al., 2009; Sánchez-Tirado et al., 2017) or pesticides (Shi et al., 2018), screenprinted dual carbon electrodes (SPdCEs) appear as suitable platforms to develop robust and reproducible electrochemical assays as they allow differential measurements by using one electrode as a blank electrode. It was recently demonstrated that such a dual device allows the reduction of both inter-electrode variations and total measurement time (Shi et al., 2018).

In this study, we describe a novel electrochemical immunosensor composed of two working electrodes for easy and rapid detection of fluoroquinolones in meat from different species. The detection of enrofloxacin (EF) was based on the competition between free EF and a newly synthesized conjugate, difloxacin-ferrocene, for their binding onto immobilized antibodies (Figure 1). To the best of our knowledge, the conjugation of enrofloxacin with ferrocene has never been 
described in literature. Differential pulse voltammetry (DPV) was employed to reveal the binding of difloxacin-ferrocene on immobilized antibodies, and the presence of free EF signal induced a proportional decrease of output signal. Finally, the proposed immunosensor was applied to the detection of EF in different meat samples with reduced preliminary processing.
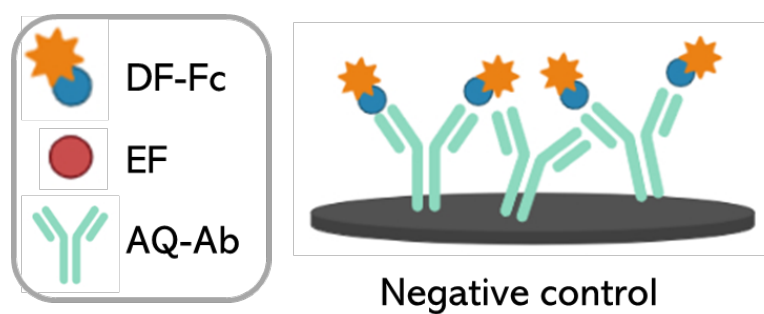

Negative control

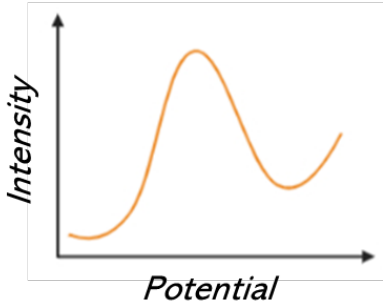

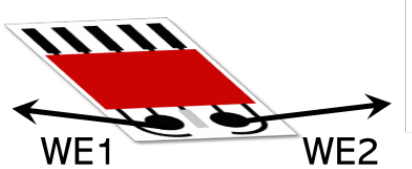

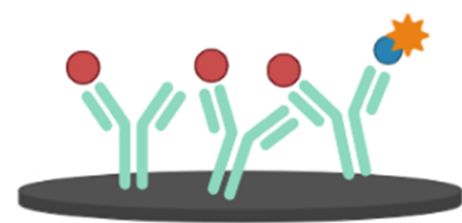

Sample test

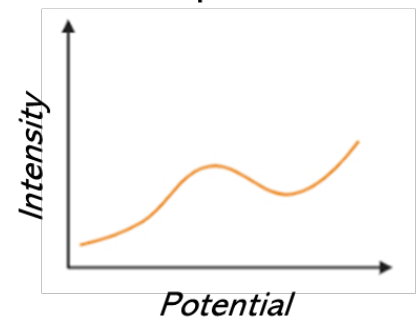

Figure 1. Detection principle of electrochemical dual immunosensor for EF detection. Working electrode 1

(WE1): In the absence of EF (negative control), the binding of DF-Fc onto anti-quinolone antibodies (AQ-Ab) leads to a high electrochemical signal; Working electrode 2 (WE2): In the presence of EF, competition takes place leading to a decrease in DF-Fc binding, which results in a lower electrochemical signal.

\section{Material and Methods}

\subsection{Reagents and apparatus}

4-aminobenzoïc acid, amoxicillin, ampicillin, bovine serum albumin (BSA), chloramphenicol, dichloromethane, disodium hydrogenophosphate $\left(\mathrm{Na}_{2} \mathrm{HPO}_{4}\right)$, ethanolamine, anhydrous ethyl acetate 99,8\%, hydrochloric acid 37\%, kanamycin, magnesium sulfate $\left(\mathrm{MgSO}_{4}\right)$, methanol, 2-(N-morpholino)ethanesulfonic acid (MES), N-hydroxysuccinimide (NHS), potassium chloride $(\mathrm{KCl})$, potassium dihydrogenophosphate $\left(\mathrm{KH}_{2} \mathrm{PO}_{4}\right)$, sodium carbonate $\left(\mathrm{Na}_{2} \mathrm{CO}_{3}\right)$, sodium chloride $(\mathrm{NaCl})$, sodium nitrite $\left(\mathrm{NaNO}_{2}\right)$, spectinomycin, sulfuric acid $98 \%$, tetracycline hydrochloride, and Tween ${ }^{\circledR} 20$ were purchased from Sigma-Aldrich (Saint-Quentin-Fallavier, 
France). 1-Ethyl-3-(3-dimethylaminopropyl)carbodiimide (EDC), ciprofloxacin, difloxacin hydrochloride, enoxacin, enrofloxacin, flumequine, norfloxacin, pefloxacin and pipemidic acid were from Alfa Aesar (Kandel, Germany), benzotriazol-1-yloxytris(dimethylamino)phosphonium hexafluorophosphate (BOP) and triethylamine from Merck (Saint Quentin Fallavier, France), methanol and dichloromethane from VWR Chemicals and aminoferrocene from Tokyo Chemical Industry (Zwijndrecht, Belgium). Polyclonal anti-quinolone antibodies from sheep were purchased from Abcam (Cambridge, United Kingdom).

Electrochemical measurements were performed using an Autolab PGSTAT100 potentiostat/galvanostat from Metrohm Autolab BV (Utrecht, Netherlands) driven by Nova 1.11 software. Mass spectral analysis was performed using electrospray ionization mass spectrometry (ESI-MS) (Thermo Scientific, France). Liquid chromatography coupled with mass spectrometry (LC-MS) analyses were carried out using a Thermo Fisher Scientific Accela LC/MS device, coupled to a LCQ Fleet equipped with an electrospray ionization source and a 3D ion-trap analyzer.

\subsection{Synthesis of difloxacin-ferrocene (DF-Fc) conjugate}

The difloxacin-ferrocene (DF-Fc) conjugate was easily produced by a one-step synthesis. Difloxacin (43 mg, $0.1 \mathrm{mmol}, 1 \mathrm{eq})$ was dissolved in dichloromethane $(10 \mathrm{~mL})$ under stirring. Benzotriazol-1-yloxytris(dimethylamino)phosphonium hexafluorophosphate (BOP) (65 mg, 0.15 mmol, $1.5 \mathrm{eq})$ was added followed by a first moiety of triethylamine $(20 \mu \mathrm{L}, 0.15 \mathrm{mmol}, 1.5 \mathrm{eq})$ in order to facilitate the dissolution of difloxacin. After 2-3 min of stirring, aminoferrocene (20 mg, $0.1 \mathrm{mmol}, 1 \mathrm{eq})$ was introduced followed by the second moiety of triethylamine $(20 \mu \mathrm{L}, 0.15 \mathrm{mmol}$, $1.5 \mathrm{eq})$. The mixture was left to react overnight and a dark brown color appeared. The organic layer was diluted in ethyl acetate and washed with $1 \mathrm{M} \mathrm{HCl}$ (to eliminate unreacted ferrocene), and $\mathrm{Na}_{2} \mathrm{CO}_{3} 10 \%(\mathrm{w} / \mathrm{v})$ (to eliminate the unreacted difloxacin) and lastly with saturated $\mathrm{NaCl}$ (to eliminate traces of water). Finally, the product was dried over $\mathrm{MgSO}_{4}$, filtered through Büchner funnel, evaporated and lyophilized. A stock solution of DF-Fc was prepared by dilution of $1 \mathrm{mg}$ of 
140 lyophilized powder in $1 \mathrm{~mL}$ methanol. Difloxacin, aminoferrocene and DF-Fc were analyzed by

141 LC-MS by injecting $1 \mathrm{mg} . \mathrm{L}^{-1}$ of each solution prepared in methanol.

142 2.3. Fabrication of screen-printed dual carbon electrodes (SPdCEs)

144 (Weymouth, United Kingdom) screen-printing system according to a new dual-electrode design

145 (Figure 2A): two working electrodes (4 mm diameter disk) made of carbon paste (Electrodag 423

146 SS, Scheemda, Netherlands) with two carbon graphite counter electrode $(16 \mathrm{~mm} \times 0.8 \mathrm{~mm}$, curved 147 paths), shared a unique pseudo-reference electrode $(5 \mathrm{~mm} \times 1.5 \mathrm{~mm}$ straight path $)$ made of $148 \mathrm{Ag} / \mathrm{AgCl}$ paste (Acheson Electrodag PF-407C, Scheemda, Netherlands). An insulating paint was 149 used to isolate the connectors from the measurement area. 
A)
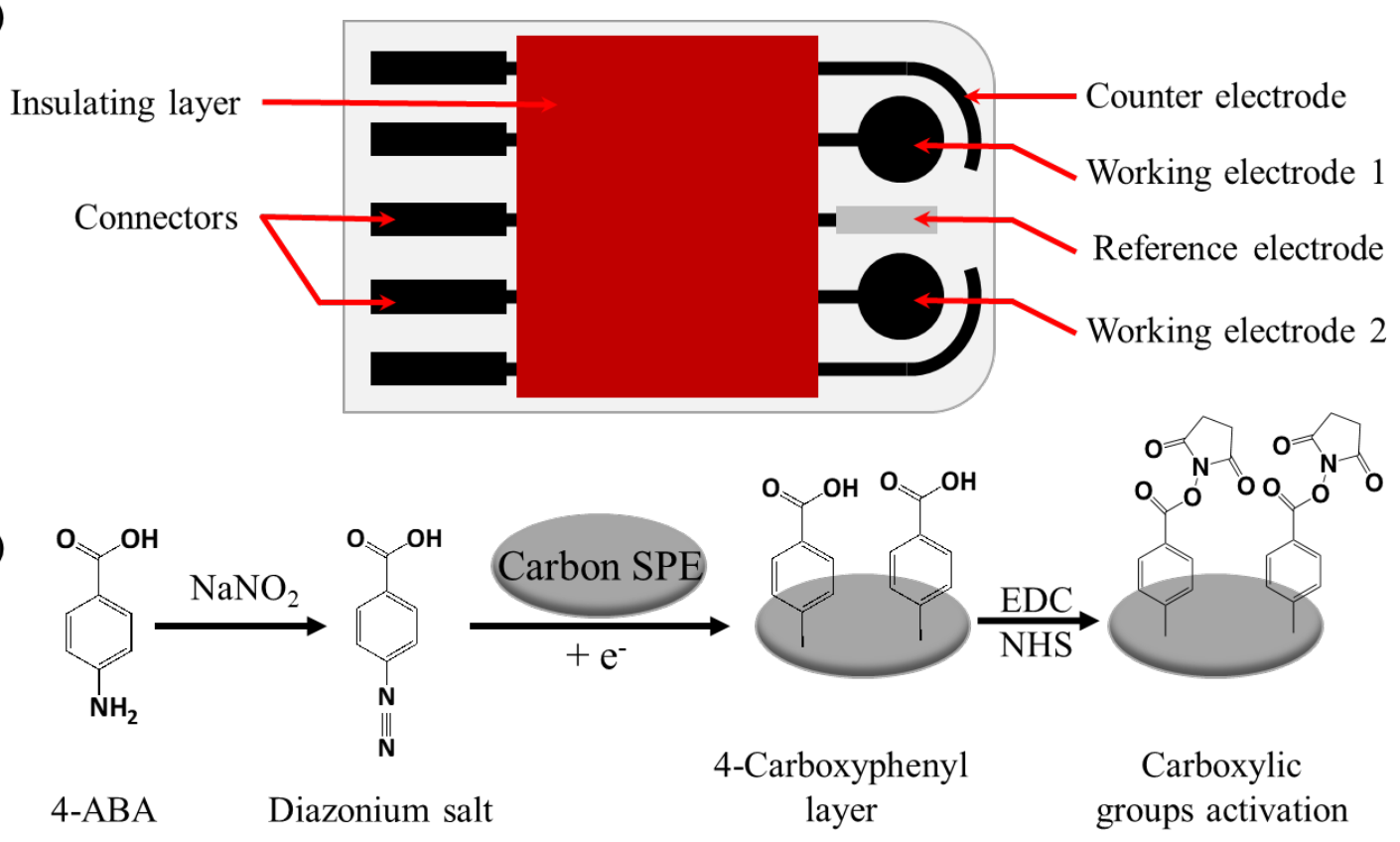

B)

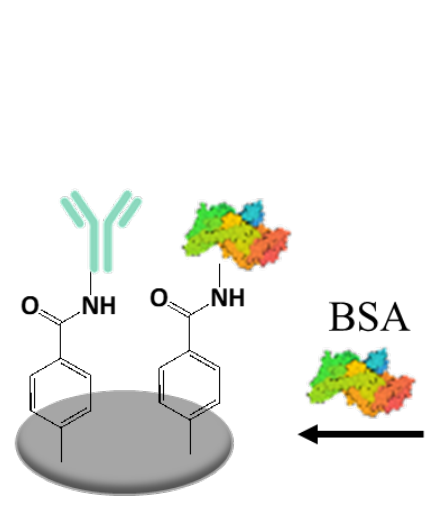

Blocking step

Figure 2. A) Design of the new screen-printed dual working-electrodes device. B) Steps of electrochemical immunosensor elaboration.

\subsection{Activation of electrode surface and antibodies immobilization}

Figure 2B describes each step of the electrochemical immunosensor fabrication. Before surface modification, the SPdCEs were electrochemically pre-treated by applying five voltammetric scans from +1.0 to $-1.5 \mathrm{~V}$ vs. $\mathrm{Ag} / \mathrm{AgCl}$ in a sulfuric acid solution $\left(0.5 \mathrm{M} \mathrm{H}_{2} \mathrm{SO}_{4}\right)$ containing $0.1 \mathrm{M}$ $\mathrm{KCl}$ (Dekanski et al., 2001). As previously described, the surface was activated though electrografting of a diazonium salt. $4 \mathrm{~mL}$ of reagent was prepared by mixing $1 \mathrm{M} \mathrm{NaNO}_{2}$ with 2 $\mathrm{mM}$ of 4-aminobenzoic acid in $0.5 \mathrm{M} \mathrm{HCl}$ (Paniel et al., 2017). After 5 min of reaction at room temperature, surface 4-carboxyphenyl groups were generated by performing a linear sweep 
voltammetry from +0.4 to $-0.6 \mathrm{~V} v$ s. $\mathrm{Ag} / \mathrm{AgCl}$ (Paniel et al., 2017). This electro-grafting was followed by activation of carboxylic groups using EDC/NHS: $30 \mu \mathrm{L}$ of $100 \mathrm{mM}$ MES buffer pH 5.5 containing $100 \mathrm{mM}$ EDC and $25 \mathrm{mM}$ NHS were incubated onto each working electrode during $2 \mathrm{~h}$ at room temperature. After washing the electrode with deionized water, $20 \mu \mathrm{L}$ of anti-quinolone antibodies prepared in $0.1 \mathrm{M}$ PBS pH 7.4 were deposited onto the activated surface and allowed to react for $2 \mathrm{~h}$ at room temperature. A non-specific adsorption control was prepared by using $1 \mathrm{M}$ ethanolamine instead of antibodies. After the drop removal, modified SPdCEs were finally incubated with $30 \mu \mathrm{L}$ of $1 \%(\mathrm{w} / \mathrm{v})$ BSA overnight at $4{ }^{\circ} \mathrm{C}$ to block unreacted succinimide groups. The electrochemical immunosensor was then ready for enrofloxacin determination.

\subsection{Immunosensor electrochemical characterization}

Characterization of SPdCEs was performed in the presence of 2.5-100 $\mu \mathrm{g} \cdot \mathrm{mL}^{-1} \mathrm{DF}-\mathrm{Fc}$ prepared in $0.1 \mathrm{M}$ PBS pH 7.4 containing $10 \%(\mathrm{v} / \mathrm{v})$ methanol. Differential pulse voltamogramms (DPV) were recorded by scanning the potential between -0.6 and $+0.5 \mathrm{~V}$ vs. $\mathrm{Ag} / \mathrm{AgCl}$ (step 0.001 $\mathrm{V}$, modulation amplitude $0.2 \mathrm{~V}$, modulation time $0.02 \mathrm{~s}$, modulation time $0.1 \mathrm{~s}$, scan rate 0.0168 $\mathrm{V} / \mathrm{s})$.

For immunosensor optimization, one working electrode was used as negative control (in the absence of EF) and the other for the detection of EF, each condition was tested in triplicate. For this purpose, $30 \mu \mathrm{L}$ of DF-Fc (negative control) or $30 \mu \mathrm{L}$ of a mix of DF-Fc and EF (positive control) were deposited onto the corresponding working electrodes and incubated for $45 \mathrm{~min}$. After washing the electrodes with PBS buffer containing 0.05\% (v/v) Tween-20, $300 \mu \mathrm{L}$ of $0.1 \mathrm{M}$ PBS pH 7.4 were deposited on the whole dual-electrode surface to perform DPV measurements. Different DFFc concentrations (5 to $100 \mu \mathrm{g} \cdot \mathrm{mL}^{-1}$ ), anti-quinolone antibodies concentrations (3.65 to 3650 ng. $\mathrm{mL}^{-1}$ ) and incubation times (5 to $60 \mathrm{~min}$ ) were tested to determine optimal experimental conditions for the detection of EF at $0.1 \mu \mathrm{g} \cdot \mathrm{mL}^{-1}$. For each optimization step, the ratio IWE2/IWE1 was calculated, where $\mathrm{I}_{\mathrm{WE} 1}$ is the current intensity measured in the absence of EF (negative control) and $\mathrm{I}_{\mathrm{WE} 2}$ is the current intensity measured in the presence of EF. Each intensity value was corrected by 
the signal measured in the absence of antibodies, corresponding to the non-specific adsorption of DF-Fc. Optimal conditions corresponded to those leading to the lower ratio. Finally, a calibration curve was established using EF solutions at concentrations ranging from 0.001 to $0.1 \mu \mathrm{g}^{\mathrm{mL}} \mathrm{mL}^{-1}$. This dose-response curve was fitted by non-linear regression using the logistic equation (Eq.1) by Origin 8.6 program:

Equation 1. Logistic equation for the description of the dose-response curve.

$$
\mathrm{I}_{\mathrm{WE} 2} / \mathrm{I}_{\mathrm{WE} 1}=\frac{\mathrm{B}-\mathrm{A}}{1+\left(\frac{[\mathrm{EF}]}{\mathrm{EC}_{50}}\right)^{\mathrm{P}}}+\mathrm{A}
$$

where $\mathrm{A}$ is the $\mathrm{y}$-value at the bottom of the plateau of the curve, B is the $\mathrm{y}$-value at the top plateau of the curve, $\mathrm{EC}_{50}$ is the $\mathrm{EF}$ concentration required to halve the $\mathrm{I}_{\mathrm{WE} 2} / \mathrm{I}_{\mathrm{WE} 1}$ ratio, and $\mathrm{P}$ is the calculated logistical power.

\subsection{Meat samples preparation}

Incurred meat samples were obtained from the sample bank built by Serrano et al. (2020) from pigs treated with enrofloxacin (Baytriluno, Bayer, Leverkusen, Germany). Muscle samples from loins, sirloins, forequarters and hindquarters were kept frozen at $-20^{\circ} \mathrm{C}$ and analyzed by HPLC-FLD according to an accredited method (International Organization for Standardization (ISO) 17025:2017). The concentrations described ranged between $18 \pm 3$ and $1044 \pm 44 \mu \mathrm{g} \cdot \mathrm{kg}^{-1}$.

In order to perform immunosensor analysis, a previous step of extraction of the serum was needed. Meat serum was obtained using an extraction protocol optimized for the analysis of antimicrobials in meat (Mata et al., 2014). Briefly, a piece of 3-4 g of muscle was placed into a 50$\mathrm{mL}$ Falcon tube and microwaved in defrost position for $3 \mathrm{~min}$ in a water bath. The meat serum produced during this step was collected and centrifuged 3 min at $4000 \mathrm{~g}$. The supernatant was analyzed with the electrochemical immunosensor without any other treatment. A certified freeantibiotic meat sample from this bank was used as negative control. 


\subsection{Detection of fluoroquinolones in meat sample with the electrochemical immunosensor}

The matrix effect of meat serum on the immunosensor response was analyzed by determining the ratio $\mathrm{I}_{\mathrm{WE} 2} / \mathrm{IWE}_{\mathrm{WE}}$ in buffer solution containing $20-80 \%(\mathrm{v} / \mathrm{v})$ meat serum certified free of antibiotics.

The incurred meat serums were diluted 1:5 in the detection solution $\left(50 \mu \mathrm{g} \cdot \mathrm{mL}^{-1} \mathrm{DF}-\mathrm{Fc}\right.$ in PBS buffer $\mathrm{pH} 7,4$ containing $10 \%(\mathrm{v} / \mathrm{v})$ methanol). A negative control was also prepared with the free-antibiotic certified meat. These solutions were incubated onto modified SPdCEs: the negative control was incubated onto WE1 and incurred meat extract was analyzed on the WE2. The ratio $\mathrm{I}_{\mathrm{WE} 2} / \mathrm{IWE}_{\mathrm{WE}}$ was calculated for each incurred meat. Fluoroquinolone concentrations were then determined using the calibration curve (Eq.1).

\section{Results and Discussion}

\subsection{Synthesis of difloxacin-ferrocene conjugate}

The working principle of the immunosensor is based on the competition between free EF and a newly synthesized conjugate, difloxacin-ferrocene (DF-Fc) for their binding to immobilized antibodies. Difloxacin is another fluoroquinolone that was selected due to its lower affinity for antiquinolone antibodies (18\% relative binding, according to Abcam product datasheet), which allows promoting the binding of EF during competition step. The synthesis of DF-Fc conjugate was based on the formation of an amide bond between difloxacin (1) and the redox probe aminoferrocene (2) (Figure 3A). This one-step synthesis was mediated by a coupling agent, benzotriazol-1yloxytris(dimethylamino)phosphonium hexafluorophosphate (BOP), allowing the activation of difloxacin hydroxyl group. The purity of the resulting DF-Fc conjugate (3) was controlled by liquid chromatography coupled with mass spectrometry (LC-MS), showing a unique molecular ion at $583.04 \mathrm{~g} / \mathrm{mol}$ that corresponds exactly to the protonated DF-Fc molar mass (Supplementary data, Figure S1). 
A)

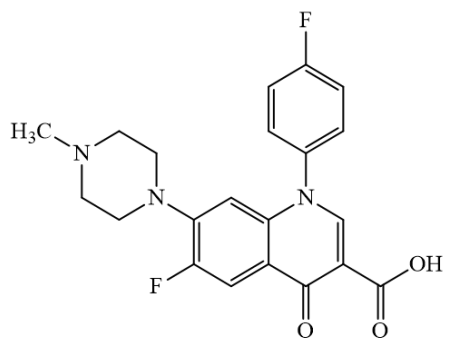

(1)

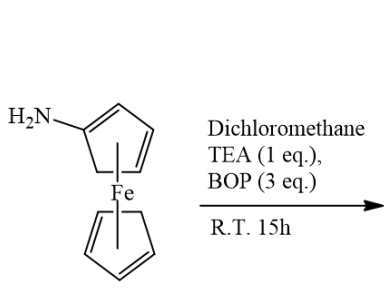

(2)

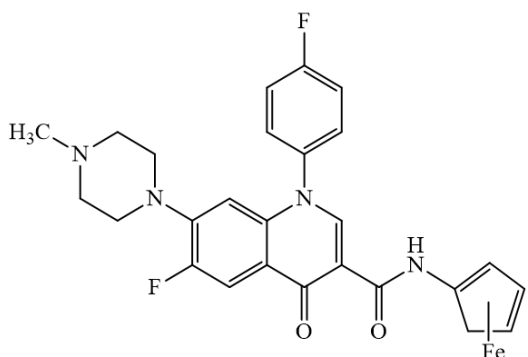

(3)
B)

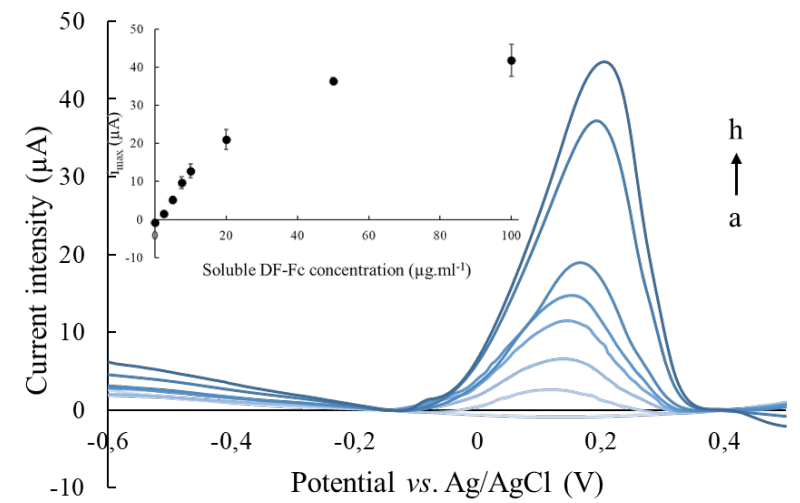

C)

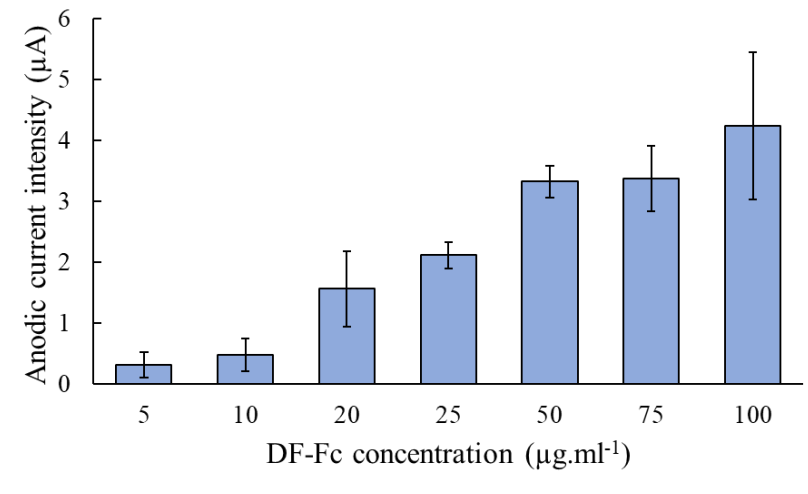

Figure 3. A) Synthesis of difloxacin-ferrocene conjugate (3) by the formation of an amide bond between aminoferrocene (1) and difloxacin (2). B) DPV scans (from -0.6 to $+0.5 \mathrm{~V}$; step $0.001 \mathrm{~V}$, modulation amplitude $0.2 \mathrm{~V}$, modulation time $0.02 \mathrm{~s}$, modulation time $0.1 \mathrm{~s}$, scan rate $\left.0.0168 \mathrm{~V} \cdot \mathrm{s}^{-1}\right)$ in the presence of $0(\mathrm{a}), 2.5(\mathrm{~b}), 5$

(c), 7.5 (d), 10 (e), 20 (f), 50 (g) and 100 (h) $\mu \mathrm{g} \cdot \mathrm{mL}^{-1}$ DF-Fc (in $0.1 \mathrm{M}$ PBS pH 7.4 containing 10\% (v/v) intensity measured with the immunosensor after incubation of 5-100 $\mu \mathrm{g} \cdot \mathrm{mL}^{-1} \mathrm{DF}-\mathrm{Fc}$ (antibody theoretical loading:

\subsection{Electrochemical characterization of difloxacin-ferrocene conjugate}

Firstly, the newly synthesized difloxacin-ferrocene conjugate (DF-Fc) was characterized by carrying out differential pulsed voltammetry (DPV) experiments between -0.6 and $+0.5 \mathrm{~V} v s$. $\mathrm{Ag} / \mathrm{AgCl}$ in $0.1 \mathrm{M}$ PBS pH 7.4 containing $10 \%(\mathrm{v} / \mathrm{v})$ methanol to improve the solubility of the conjugate (Figure 3B). Oxidation of conjugate-linked $\mathrm{Fc}$ was observed at around $+0.2 \mathrm{~V} v s$. $\mathrm{Ag} / \mathrm{AgCl}$, and the obtained anodic current allowed establishing a calibration curve for DF-Fc concentrations ranging from 2.5 to $100 \mu \mathrm{g} \cdot \mathrm{mL}^{-1}$ (Figure 3B inset). The resulting curve follows a hyperbolic shape, with a linear range between 2.5 and $10 \mu \mathrm{g} \cdot \mathrm{mL}^{-1}$, and a sensitivity of $1202 \mu \mathrm{A} \cdot \mathrm{mg}^{-}$ ${ }^{1} . \mathrm{mL}$. It was calculated that variability of the signal measured with 10 different electrodes in 
presence of $50 \mu \mathrm{g} \cdot \mathrm{mL}^{-1} \mathrm{DF}-\mathrm{Fc}$ was $2 \%$, showing that home-made screen-printed electrodes are suitable transducers for DF-Fc detection.

In a second step, the affinity of DF-Fc for anti-quinolone antibodies was evaluated by incubating the designed immunosensor with DF-Fc at concentrations ranging from 5 to $100 \mu \mathrm{g} . \mathrm{mL}^{-1}$ (Figure 3C). For each concentration, current intensities were corrected by the signal measured in the absence of antibodies, corresponding to the non-specific adsorption of DF-Fc. It was shown that the corrected current increases linearly with DF-Fc concentration and reaches a plateau at $3.3 \mu \mathrm{A}$ in the presence of $50 \mu \mathrm{g} \cdot \mathrm{mL}^{-1} \mathrm{DF}-\mathrm{Fc}$, corresponding to the saturation of immobilized antibodies (Figure 3C). In these conditions, a satisfying variability was measured with a relative standard deviation of $4.3 \%$, measured using three different electrodes.

\subsection{Performance of the electrochemical immunosensors for the detection of enrofloxacin}

The proposed electrochemical immunosensor was used to detect EF based on a competition between EF and DF-Fc for their binding to immobilized antibodies (Figure 1). Due to the higher affinity of antibodies for EF than for DF-Fc, the preferential binding of EF led to a decrease of electrochemical signal. The immunosensor performances were optimized in order to reach the desired threshold of $0.1 \mu \mathrm{g} \cdot \mathrm{mL}^{-1} \mathrm{EF}$. The new dual working electrode design allowed the simultaneous measurement of negative control on WE1 (in the absence of EF) and positive control on WE2 (for various EF concentrations). The measured currents were corrected from the error due to non-specific binding of DF-Fc, which was calculated from triplicate measurements prior to each measurement series. The ratios $\mathrm{I}_{\mathrm{WE} 2} / \mathrm{I}_{\mathrm{WE} 1}$ were calculated for different DF-Fc concentrations, using various antibody loadings and different incubation times. It was shown that the detection of EF was optimal using an antibody loading of $1.46 \mathrm{ng}$ in presence of $50 \mu \mathrm{g} \cdot \mathrm{mL}^{-1} \mathrm{DF}-\mathrm{Fc}$ and using an incubation time of $45 \mathrm{~min}$. Under these optimal conditions, a calibration curve was established with EF at concentrations ranging from 0.001 to $0.1 \mu \mathrm{g} \cdot \mathrm{mL}^{-1}$ (Figure $4 \mathrm{~A}$ ). The IWE2/IWE1 ratio decreases with the increase of EF concentration, showing a typical behavior of a competitive assay. According the logistic model (Eq.1) used to fit this dose-response curve, the EF concentration necessary to 
halve the signal $\left(\mathrm{EC}_{50}\right)$ was $0.010 \mu \mathrm{g} \cdot \mathrm{mL}^{-1}$ and the limit of detection calculated for $90 \%$ response ratio was $0.003 \mu \mathrm{g} \cdot \mathrm{mL}^{-1}$. These results show that the performance of the developed sensor is suitable for the determination of EF in meat samples.

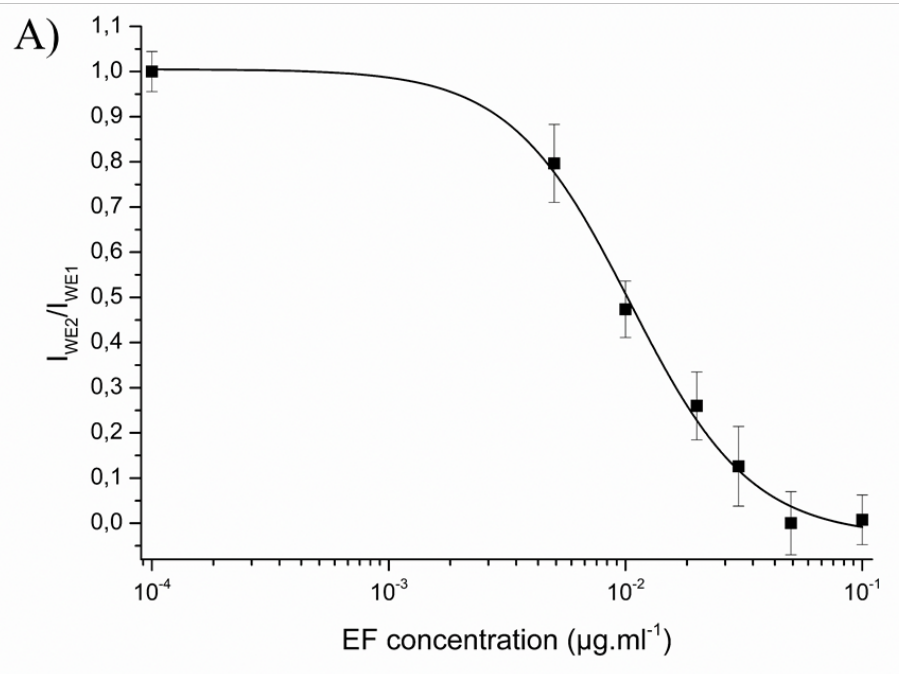

B)

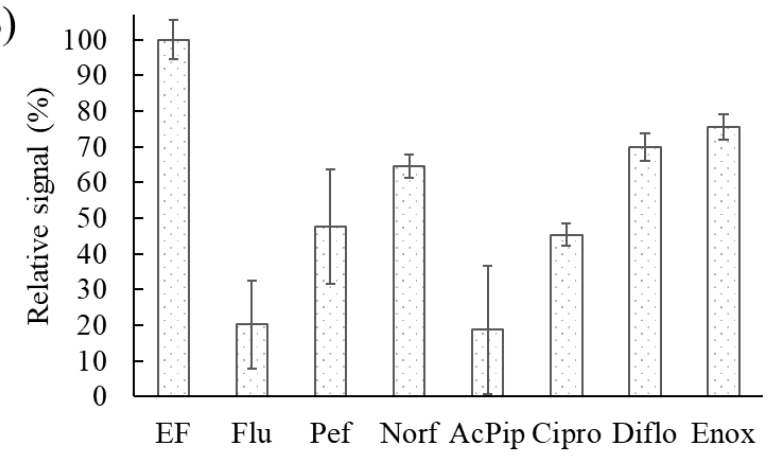

C)

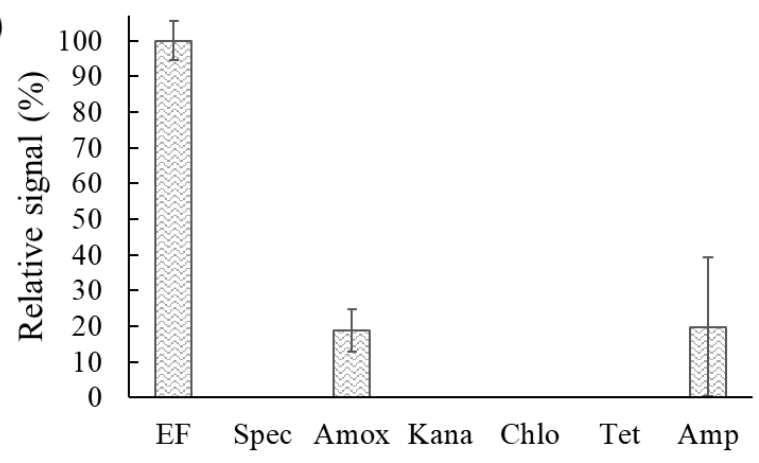

Figure 4. A) Dose response curve measured in the presence of 0.001 to $0.1 \mu \mathrm{g} \cdot \mathrm{mL}^{-1} \mathrm{EF}$ and $50 \mu \mathrm{g} \cdot \mathrm{mL}^{-1} \mathrm{DF}-\mathrm{Fc}$ (in PBS pH 7.4, incubation time 45 min, antibody $1.46 \mathrm{ng}$ ). Curve fitting using a logistical model (black line) exhibiting the following equation: $\mathrm{I}_{\mathrm{WE} 2} / \mathrm{I}_{\mathrm{WE} 1}=\left(1 /\left(1+([\mathrm{EF}] / 0.010)^{1.84}\right)\right)\left(\mathrm{R}^{2}=0.989\right)$. B) Relative signal (expressed in percentage of EF signal) measured in the presence of $0.1 \mu \mathrm{g} \cdot \mathrm{mL}^{-1}$ of spectinomycin (Spec), amoxicillin (Amox), kanamycin (Kana), chloramphenicol (Chlo), tetracycline (Tet) and ampicillin (Amp). C) Relative signal (expressed in percentage of EF signal) measured in the presence of $0.1 \mu \mathrm{g} \cdot \mathrm{mL}^{-1}$ quinolones: flumequine (Flu), pefloxacin (Pef), norfloxacin (Norf), pipemidic acid (AcPip), ciprofloxacin (Cipro), difloxacin (Diflo) and enoxacin (Enox).

\subsection{Selectivity towards other antibiotics}

The selectivity of the electrochemical immunosensor was evaluated by incubating modified SPdCEs with $0.1 \mu \mathrm{g} \cdot \mathrm{mL}^{-1}$ of various antibiotics from different classes: spectinomycin and kanamycin (aminoglycosides class), chloramphenicol (phenicols class), tetracycline (cyclines class) 
and amoxicillin and ampicillin ( $\beta$-lactams class). According to Figure $4 \mathrm{~B}$, these antibiotics do not significantly interfere with EF detection.

The immunosensor was then tested using different quinolones including flumequine, pefloxacin, norfloxacin, pipemidic acid, ciprofloxacin, difloxacin and enoxacin (Figure 4C). Due to the nonspecificity of antibodies for one fluoroquinolone, an inhibition was detected for all the fluoroquinolones tested. It must be stressed that flumequine and pipemidic acid presented lower signals, probably due to the absence of a piperazine ring in flumequine and of a fluor atom in pipemidic acid (Supplementary data, Figure S2). These two elements thus seem to be mandatory for antibodies specific recognition.

\subsection{Reproducibility and storage stability of the immunosensor}

The immunosensor reproducibility was evaluated by testing the response of five sensors, prepared independently under the same conditions, in the presence of $0.1 \mu \mathrm{g} \cdot \mathrm{mL}^{-1}$ enrofloxacin. The corresponding $\mathrm{I}_{\mathrm{WE} 2} / \mathrm{I}_{\mathrm{WE} 1}$ ratios were calculated and a relative standard deviation of $5.5 \%$ was obtained, indicating that the electrochemical immunosensor shows a satisfactory reproducibility.

Long-term stability was also evaluated using 6 immunosensors prepared in the same optimal conditions and stored during one month at $4{ }^{\circ} \mathrm{C}$. The results showed that $94 \%$ of current intensity was conserved after one month and that a comparable IWE2/IWE1 ratio was obtained in the presence of $0.1 \mu \mathrm{g} . \mathrm{mL}^{-1} \mathrm{EF}$, showing an appropriate stability of this electrochemical immunosensor. These storage conditions could allow the mass production of the proposed immunosensor but need further optimization for potential commercialization.

\subsection{Detection of fluoroquinolones in meat samples}

The proposed immunosensor was used to detect EF from meat samples. Firstly, serum from antibiotic-free meat samples was extracted and tested using the immunosensor to evaluate its potential matrix effect. The electrochemical response (IWE1) was recorded in the presence of 20$80 \%(\mathrm{v} / \mathrm{v})$ of meat serum in the incubation solution. The current intensity $\left(\mathrm{I}_{\mathrm{WE} 2}\right)$ was measured in parallel with $20-80 \%(\mathrm{v} / \mathrm{v})$ of the serum spiked with $0.1 \mu \mathrm{g} \cdot \mathrm{mL}^{-1} \mathrm{EF}$, and the response ratios 
$\mathrm{I}_{\mathrm{WE} 2} / \mathrm{I}_{\mathrm{WE} 1}$ were determined for each serum percentage. The achieved results were reported as relative percentages, in comparison with the ratio measured without serum (Figure 5A). It was shown that meat serum does not affect the immunosensor response when used at a volume ratio of $20 \%$, while higher amounts dramatically decrease its response. The same ratio of $20 \%$ was thus tested using muscle meat serums from other animals (chicken, beef, lamb, duck, horse and turkey), which were extracted and analyzed using the same protocol. As shown in Figure 5B, the addition of $0.1 \mu \mathrm{g} . \mathrm{mL}^{-1} \mathrm{EF}$ led to very similar relative signals, showing that the optimized protocol is suitable for the detection of fluoroquinolones in a wide range of meats.
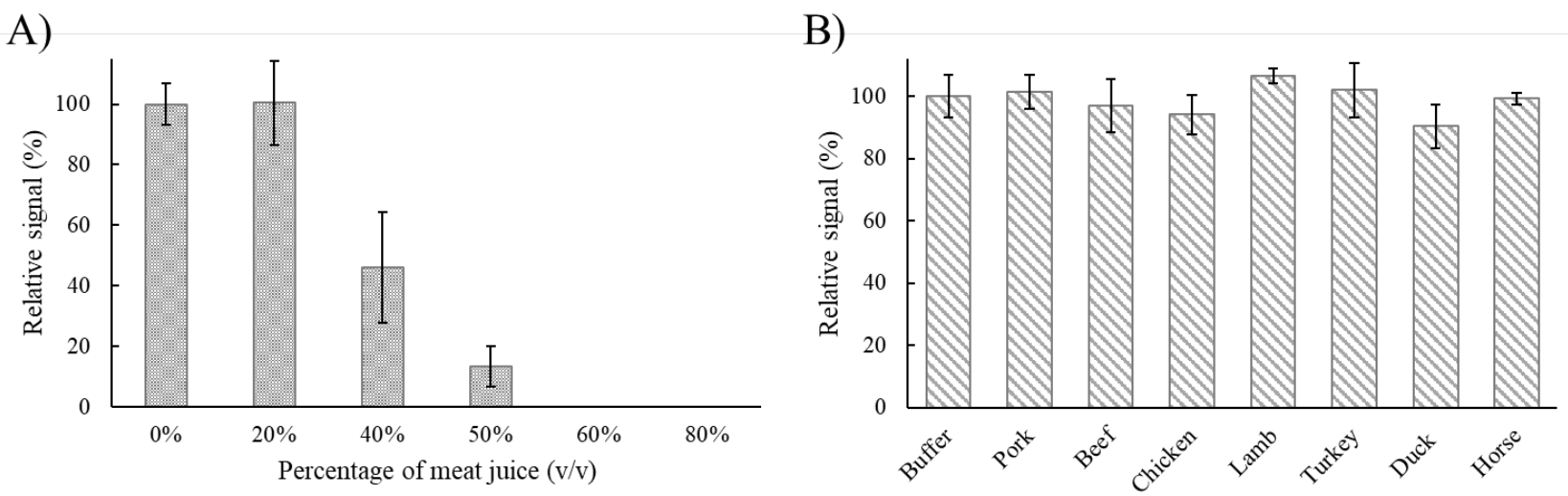

Figure 5. A) Immunosensor relative signal (in comparison with the $\mathrm{I}_{\mathrm{WE} 2} / \mathrm{I}_{\mathrm{WE} 1}$ ratio obtained in the absence of meat serum) measured in the presence of $0.1 \mu \mathrm{g} \cdot \mathrm{mL}^{-1} \mathrm{EF}$ and $20-80 \%(\mathrm{v} / \mathrm{v})$ of meat serum. B) Immunosensor relative signal (in comparison with the $\mathrm{I}_{\mathrm{WE} 2} / \mathrm{I}_{\mathrm{WE} 1}$ ratio obtained in buffer) measured in the presence of $20 \%(\mathrm{v} / \mathrm{v})$ meat serums from pork, beef, chicken, lamb, turkey, duck and horse meat, spiked with $0.1 \mu \mathrm{g} \cdot \mathrm{mL}^{-1} \mathrm{EF}$.

Incurred samples obtained from pigs treated with different doses of fluoroquinolones were analyzed using the developed immunosensor. For each piece of meat, the IWE2/IWE1 ratio was determined using the previously described strategy, allowing the determination of a fluoroquinolone concentration expressed in $\mu \mathrm{g} . \mathrm{L}^{-1}$. Figure 6 presents the correlation between the fluoroquinolone concentration found by HPLC-FLD (Serrano et al., 2020) and data obtained from the analysis performed with the new immunosensor. A satisfying correlation coefficient $\left(\mathrm{R}^{2}=0.975\right)$ was found between the results achieved using both technologies, showing that the electrochemical 
immunosensor could be a very useful tool for the detection of fluoroquinolone antibiotics in meat samples. Moreover, it was shown that the simplicity of the extraction process was sufficient to detect these antibiotics with accuracy.

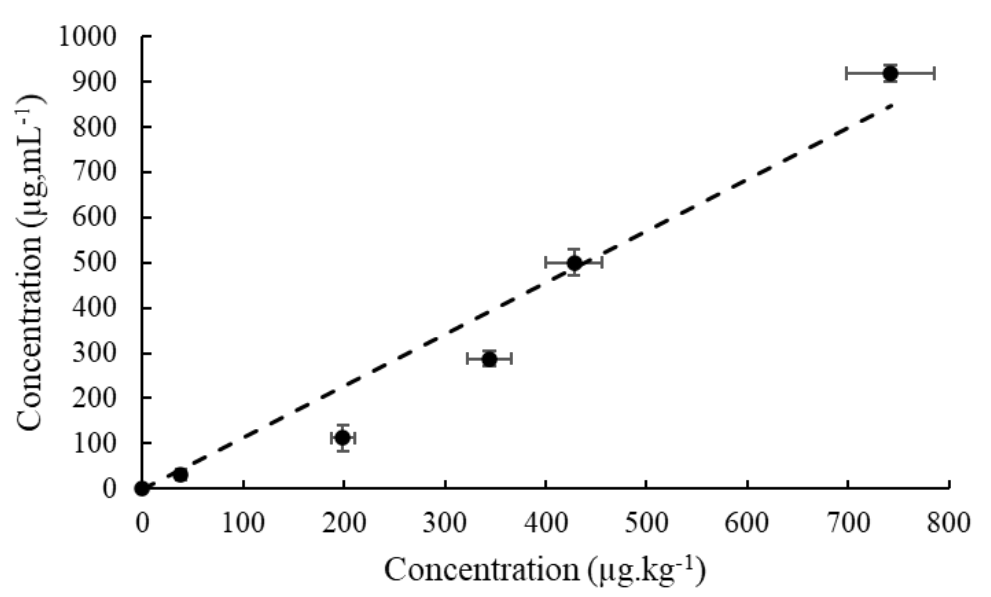

Figure 6. Correlation between the fluoroquinolone concentration determined by the proposed electrochemical immunosensor (expressed in $\mu \mathrm{g} . \mathrm{L}^{-1}$ ) and determined by HPLC-FLD (expressed in $\mu \mathrm{g} \cdot \mathrm{kg}^{-1}$ ) for each incurred meat sample tested. The dotted line exhibited the following equation: $y=1.1408 x\left(R^{2}=0.975\right)$.

\section{Conclusions}

This work describes for the first time the development of an electrochemical immunosensor for the detection of enrofloxacin (EF) antibiotic in meat samples. The device is based on the competitive binding of EF and a ferrocene-labelled conjugate (DF-Fc), which was synthesized and characterized by differential pulse voltammetry. Under optimal conditions, the proposed immunosensor was able to determine $\mathrm{EF}$ at concentrations ranging from 0.005 to $0.01 \mu \mathrm{g} \cdot \mathrm{mL}^{-1}$, with a detection limit of $0.003 \mu \mathrm{g} \cdot \mathrm{mL}^{-1}$. The use of a dual-working electrode design allowed taking into account the inter-electrode variability by using one electrode as negative control. This new method exhibited an acceptable stability, good reproducibility and adequate selectivity towards other antibiotics. Spiked EF was detected in pork, chicken, beef, lamb, horse, duck and turkey meats after a rapid and easy extraction method. Finally, real samples were also analyzed and led to an accurate EF quantification. 


\section{Acknowledgements}

This project was co-financed by the European Regional Development Fund (ERDF) through the Interreg V-A Spain-France-Andorra program (POCTEFA 2014-2020) (EFA (Spain-FranceAndorra) 152/16). POCTEFA aims to reinforce the economic and social integration of the FrenchSpanish-Andorran border. Its support is focused on developing economic, social, and environmental cross-border activities through joint strategies favoring sustainable territorial development. LC-MS analyses have been performed using the Biodiversité et Biotechnologies

Marines (Bio2Mar) facilities (Metabolites Secondaires Xenobiotiques Metabolomique 372 Environnementale (MSXM) platform) of the University de Perpignan Via Domitia 373 (http://bio2mar.obs-banyuls.fr/).

\section{References}

Alekshun, M. N., \& Levy, S. B. (2007). Molecular Mechanisms of Antibacterial Multidrug Resistance. Cell, 128(6), 1037-1050. https://doi.org/10.1016/j.cell.2007.03.004

Aronson, J. K. (2016). Fluoroquinolones. In J. K. Aronson (Ed.), Meyler's Side Effects of Drugs

Bahadir, E. B., \& Sezgintürk, M. K. (2016). A review on impedimetric biosensors. Artificial Cells, Nanomedicine and Biotechnology, 44(1), 248-262. https://doi.org/10.3109/21691401.2014.942456

Blondeau, J. M. (2004). Fluoroquinolones: Mechanism of action, classification, and development of resistance. Survey of Ophthalmology, 49(2 SUPPL. 2), 1-6. https://doi.org/10.1016/j.survophthal.2004.01.005

Brown, K., Uwiera, R. R. E., Kalmokoff, M. L., Brooks, S. P. J., \& Inglis, G. D. (2017). Antimicrobial growth promoter use in livestock: a requirement to understand their modes of action to develop effective alternatives. International Journal of Antimicrobial Agents, 49(1), 
390 Casas-Solvas, J. M., Ortiz-Salmerón, E., Giménez-Martínez, J. J., García-Fuentes, L., Capitán391

Vallvey, L. F., Santoyo-González, F., \& Vargas-Berenguel, A. (2009). Ferrocene-carbohydrate conjugates as electrochemical probes for molecular recognition studies. Chemistry - $A$ European Journal, 15(3), 710-725. https://doi.org/10.1002/chem.200800927

Cháfer-Pericás, C., Maquieira, Á., \& Puchades, R. (2010). Fast screening methods to detect antibiotic residues in food samples. TrAC - Trends in Analytical Chemistry, 29(9), 1038-1049. https://doi.org/10.1016/j.trac.2010.06.004

Chen, X., Xu, H., Lai, W., Chen, Y., Yang, X., \& Xiong, Y. (2012). A sensitive chromatographic strip test for the rapid detection of enrofloxacin in chicken muscle. Food Additives and Contaminants - Part A Chemistry, Analysis, Control, Exposure and Risk Assessment, 29(3), 383-391. https://doi.org/10.1080/19440049.2011.641509

Chohan, Z. H. (2009). Synthesis of organometallic-based biologically active compounds: In vitro antibacterial, antifungal and cytotoxic properties of some sulfonamide incorporated ferrocences. Journal of Enzyme Inhibition and Medicinal Chemistry, 24(1), 169-175. https://doi.org/10.1080/14756360801948766

Dechtrirat, D., Gajovic-Eichelmann, N., Wojcik, F., Hartmann, L., Bier, F. F., \& Scheller, F. W. (2014). Electrochemical displacement sensor based on ferrocene boronic acid tracer and immobilized glycan for saccharide binding proteins and E. coli. Biosensors and Bioelectronics, 58, 1-8. https://doi.org/10.1016/j.bios.2014.02.028

Dekanski, A., Stevanović, J., Stevanović, R., Nikolić, B. Ž., \& Jovanović, V. M. (2001). Glassy carbon electrodes: I. Characterization and electrochemical activation. Carbon, 39(8), 11951205. https://doi.org/10.1016/S0008-6223(00)00228-1

Diana, A., Santinello, M., Penasa, M., Scali, F., Magni, E., Alborali, G. L., Bertocchi, L., \& De Marchi, M. (2020). Use of antimicrobials in beef cattle: an observational study in the north of Italy. Preventive Veterinary Medicine, 181(January), 105032. 
Dolati, S., Ramezani, M., Nabavinia, M. S., Soheili, V., Abnous, K., \& Taghdisi, S. M. (2018). Selection of specific aptamer against enrofloxacin and fabrication of graphene oxide based label-free fluorescent assay. Analytical Biochemistry, 549, 124-129. https://doi.org/10.1016/j.ab.2018.03.021

Dunnett, M., Richardson, D. W., \& Lees, P. (2004). Detection of enrofloxacin and its metabolite ciprofloxacin in equine hair. Research in Veterinary Science, 77(2), 143-151. https://doi.org/10.1016/j.rvsc.2004.03.004

Escamilla-Gómez, V., Hernández-Santos, D., González-García, M. B., Pingarrón-Carrazón, J. M., \& Costa-García, A. (2009). Simultaneous detection of free and total prostate specific antigen on a screen-printed electrochemical dual sensor. Biosensors and Bioelectronics, 24(8), 26782683. https://doi.org/10.1016/j.bios.2009.01.043

European Medicines Agency. (2019). Categorisation of antibiotics in the European Union. Ema/Cvmp/Chmp/682198/2017, 31(December), 73. https://www.ema.europa.eu/en/documents/report/categorisation-antibiotics-european-unionanswer-request-european-commission-updating-scientific_en.pdf

Felix, F. S., \& Angnes, L. (2018). Electrochemical immunosensors - A powerful tool for analytical applications. Biosensors and Bioelectronics, 102, 470-478. https://doi.org/10.1016/j.bios.2017.11.029

Garifallou, G. Z., Tsekenis, G., Davis, F., Higson, S. P. J., Millner, P. A., Pinacho, D. G., SanchezBaeza, F., Marco, M. P., \& Gibson, T. D. (2007). Labeless immunosensor assay for fluoroquinolone antibiotics based upon an AC impedance protocol. Analytical Letters, 40(7), 1412-1422. https://doi.org/10.1080/00032710701327070

Giroud, F., Gorgy, K., Gondran, C., Cosnier, S., Pinacho, D. G., Marco, M. P., \& Sánchez-Baeza, F. J. (2009). Impedimetric immunosensor based on a polypyrrole-antibiotic model film for the label-free picomolar detection of ciprofloxacin. Analytical Chemistry, 81(20), 8405-8409. 
https://doi.org/10.1021/ac901290m

Ha, M. S., Chung, M. S., \& Bae, D. H. (2016). Simple detection of residual enrofloxacin in meat products using microparticles and biochips. Food Additives and Contaminants - Part A Chemistry, Analysis, Control, Exposure and Risk Assessment, 33(5), 817-823. https://doi.org/10.1080/19440049.2016.1179560

He, Z., Zang, S., Liu, Y., He, Y., \& Lei, H. (2015). A multi-walled carbon nanotubes-poly(1-lysine) modified enantioselective immunosensor for ofloxacin by using multi-enzyme-labeled gold nanoflower as signal enhancer. Biosensors and Bioelectronics, 73, 85-92. https://doi.org/10.1016/j.bios.2015.05.054

Hu, S., Fang, B., Huang, Z., Chen, Y., Liu, D., Xing, K., Peng, J., \& Lai, W. (2019). Using molecular descriptors for assisted screening of heterologous competitive antigens to improve the sensitivity of ELISA for detection of enrofloxacin in raw milk. Journal of Dairy Science, 102(7), 6037-6046. https://doi.org/10.3168/jds.2018-16048

Huang, X., Aguilar, Z. P., Li, H., Lai, W., Wei, H., Xu, H., \& Xiong, Y. (2013). Fluorescent $\mathrm{Ru}($ phen)32+-doped silica nanoparticles-based ICTS sensor for quantitative detection of enrofloxacin residues in chicken meat. Analytical Chemistry, 85(10), 5120-5128. https://doi.org/10.1021/ac400502v

Ionescu, R. E., Jaffrezic-Renault, N., Bouffier, L., Gondran, C., Cosnier, S., Pinacho, D. G., Marco, M. P., Sánchez-Baeza, F. J., Healy, T., \& Martelet, C. (2007). Impedimetric immunosensor for the specific label free detection of ciprofloxacin antibiotic. Biosensors and Bioelectronics, 23(4), 549-555. https://doi.org/10.1016/j.bios.2007.07.014

Khor, S. M., Liu, G., Peterson, J. R., Iyengar, S. G., \& Gooding, J. J. (2011). An Electrochemical Immunobiosensor for Direct Detection of Veterinary Drug Residues in Undiluted Complex Matrices. Electroanalysis, 23(8), 1797-1804. https://doi.org/10.1002/elan.201100205

Kivirand, K., Min, M., \& Rinken, T. (2019). Challenges and Applications of Impedance-Based Biosensors in Water Analysis. Biosensors for Environmental Monitoring. 

https://doi.org/10.5772/intechopen.89334

Lewandowski, E. M., Szczupak, Ł., Kowalczyk, A., Mendoza, G., Arruebo, M., Jacobs, L. M. C., Stączek, P., Chen, Y., \& Kowalski, K. (2020). Metallocenyl 7-ACA Conjugates: Antibacterial Activity Studies and Atomic- Resolution X-ray Crystal Structure with CTX-M $\beta$-Lactamase. Chembiochem. https://doi.org/10.1002/cbic.202000054

Liu, B., Li, M., Zhao, Y., Pan, M., Gu, Y., Sheng, W., Fang, G., \& Wang, S. (2018). A sensitive electrochemical immunosensor based on PAMAM dendrimer-encapsulated Au for detection of norfloxacin in animal-derived foods. Sensors (Switzerland), 18(6). https://doi.org/10.3390/s18061946

Martić, S., Labib, M., Shipman, P. O., \& Kraatz, H. B. (2011). Ferrocene-peptido conjugates: From synthesis to sensory applications. Dalton Transactions, 40(28), 7264-7290. https://doi.org/10.1039/c0dt01707h

Mata, L., Sanz, D., \& Razquin, P. (2014). Validation of the Explorer® 2.0 test coupled to eReader ${ }^{\circledR}$ for the screening of antimicrobials in muscle from different animal species. Food Additives and Contaminants - Part A Chemistry, Analysis, Control, Exposure and Risk Assessment, 31(9), 1496-1505. https://doi.org/10.1080/19440049.2014.934303

Mollarasouli, F., Kurbanoglu, S., \& Ozkan, S. A. (2019). The role of electrochemical immunosensors in clinical analysis. Biosensors, 9(3), 1-19. https://doi.org/10.3390/bios9030086

Nakayama, M., Ihara, T., Nakano, K., \& Maeda, M. (2002). DNA sensors using a ferroceneoligonucleotide conjugate. Talanta, 56(5), 857-866. https://doi.org/10.1016/S00399140(01)00659-2

Paniel, N., Istamboulié, G., Triki, A., Lozano, C., Barthelmebs, L., \& Noguer, T. (2017). Selection of DNA aptamers against penicillin G using Capture-SELEX for the development of an impedimetric sensor. Talanta, 162(September 2016), 232-240. https://doi.org/10.1016/j.talanta.2016.09.058 
Panzenhagen, P. H. N., Aguiar, W. S., Gouvêa, R., de Oliveira, A. M. G., Barreto, F., Pereira, V. L. A., \& Aquino, M. H. C. (2016). Investigation of enrofloxacin residues in broiler tissues using ELISA and LC-MS/MS. Food Additives and Contaminants - Part A Chemistry, Analysis, Control, Exposure and Risk Assessment, 33(4), 639-643. https://doi.org/10.1080/19440049.2016.1143566

Peris-Vicente, J., Tayeb-Cherif, K., Carda-Broch, S., \& Esteve-Romero, J. (2017). Validation of a procedure to quantify oxolinic acid, danofloxacin, ciprofloxacin and enrofloxacin in selected meats by micellar liquid chromatography according to EU Commission Decision 2002/657/EC. Electrophoresis, 38(16), 2011-2017. https://doi.org/10.1002/elps.201700159

Rezende, J. de P., Pacheco, A. F. C., Magalhães, O. F., Coelho, Y. L., Vidigal, M. C. T. R., da Silva, L. H. M., \& Pires, A. C. dos S. (2019). Polydiacetylene/triblock copolymer/surfactant nanoblend: A simple and rapid method for the colorimetric screening of enrofloxacin residue. Food Chemistry, 280, 1-7. https://doi.org/10.1016/j.foodchem.2018.12.033

Sánchez-Tirado, E., Salvo, C., González-Cortés, A., Yáñez-Sedeño, P., Langa, F., \& Pingarrón, J. M. (2017). Electrochemical immunosensor for simultaneous determination of interleukin-1 beta and tumor necrosis factor alpha in serum and saliva using dual screen printed electrodes modified with functionalized double-walled carbon nanotubes. Analytica Chimica Acta, 959, 66-73. https://doi.org/10.1016/j.aca.2016.12.034

Serrano, M. J., Mitjana, O., Bonastre, C., Laborda, A., Falceto, M. V., García-Gonzalo, D., Abilleira, E., Elorduy, J., Bousquet-Melou, A., Mata, L., Condón, S., \& Pagán, R. (2020). Is blood a good indicator for detecting antimicrobials in meat? Evidence for the development of in vivo surveillance methods. Antibiotics, 9(4). https://doi.org/10.3390/antibiotics9040175

Sharma, A., Istamboulie, G., Hayat, A., Catanante, G., Bhand, S., \& Marty, J. L. (2017). Disposable and portable aptamer functionalized impedimetric sensor for detection of kanamycin residue in milk sample. Sensors and Actuators, B: Chemical, 245, 507-515. https://doi.org/10.1016/j.snb.2017.02.002 
Shi, Q., Teng, Y., Zhang, Y., \& Liu, W. (2018). Rapid detection of organophosphorus pesticide residue on Prussian blue modified dual-channel screen-printed electrodes combing with portable potentiostat. Chinese Chemical Letters, 29(9), 1379-1382. https://doi.org/10.1016/j.cclet.2017.11.023

Skiba, J., Rajnisz, A., De Oliveira, K. N., Ott, I., Solecka, J., \& Kowalski, K. (2012). Ferrocenyl bioconjugates of ampicillin and 6-aminopenicillinic acid - Synthesis, electrochemistry and biological activity. European Journal of Medicinal Chemistry, 57, 234-239. https://doi.org/10.1016/j.ejmech.2012.09.023

Štěpnička, P. (2008). Ferrocenes: Ligands, Materials and Biomolecules. In Ferrocenes: Ligands, Materials and Biomolecules. https://doi.org/10.1002/9780470985663

Taleat, Z., Khoshroo, A., \& Mazloum-Ardakani, M. (2014). Screen-printed electrodes for biosensing: A review (2008-2013). Microchimica Acta, 181(9-10), 865-891. https://doi.org/10.1007/s00604-014-1181-1

Tenover, F. C. (2006). Mechanisms of Antimicrobial Resistance in Bacteria. American Journal of Medicine, $119(6$ SUPPL. 1). https://doi.org/10.1016/j.amjmed.2006.03.011

Tumini, M., Nagel, O. G., \& Althaus, R. L. (2019). Five-assay microbiological system for the screening of antibiotic residues. Revista Argentina de Microbiologia, 51(4), 345-353. https://doi.org/10.1016/j.ram.2019.01.002

Wang, L., Wu, X., \& Xie, Z. (2005). Determination of enrofloxacin and its metabolite ciprofloxacin by high performance capillary electrophoresis with end-column amperometric detection. Journal of Separation Science, 28(11), 1143-1148. https://doi.org/10.1002/jssc.200400110

Wang, Z., Zhang, H., Ni, H., Zhang, S., \& Shen, J. (2014). Development of a highly sensitive and specific immunoassay for enrofloxacin based on heterologous coating haptens. Analytica Chimica Acta, 820(235), 152-158. https://doi.org/10.1016/j.aca.2014.02.043

Wolfson, J. S., \& Hooper, D. C. (1985). The fluoroquinolones: Structures, mechanisms of action and resistance, and spectra of activity in vitro. Antimicrobial Agents and Chemotherapy, 28(4), 
546 Wu, C. C., Lin, C. H., \& Wang, W. S. (2009). Development of an enrofloxacin immunosensor 547 based on label-free electrochemical impedance spectroscopy. Talanta, 79(1), 62-67. https://doi.org/10.1016/j.talanta.2009.03.006

549 Wu, Q., Peng, D., Liu, Q., Bakr Shabbir, M. A., Sajid, A., Liu, Z., Wang, Y., \& Yuan, Z. (2019). A 550 novel microbiological method in microtiter plates for screening seven kinds of widely used antibiotics residues in milk, chicken egg and honey. Frontiers in Microbiology, 10(MAR), 1- 


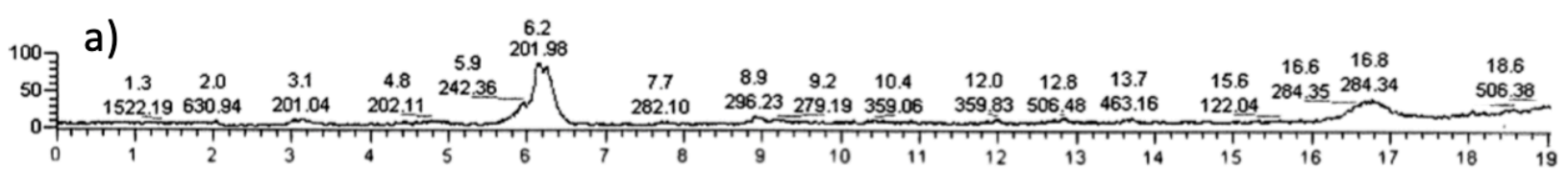

b)
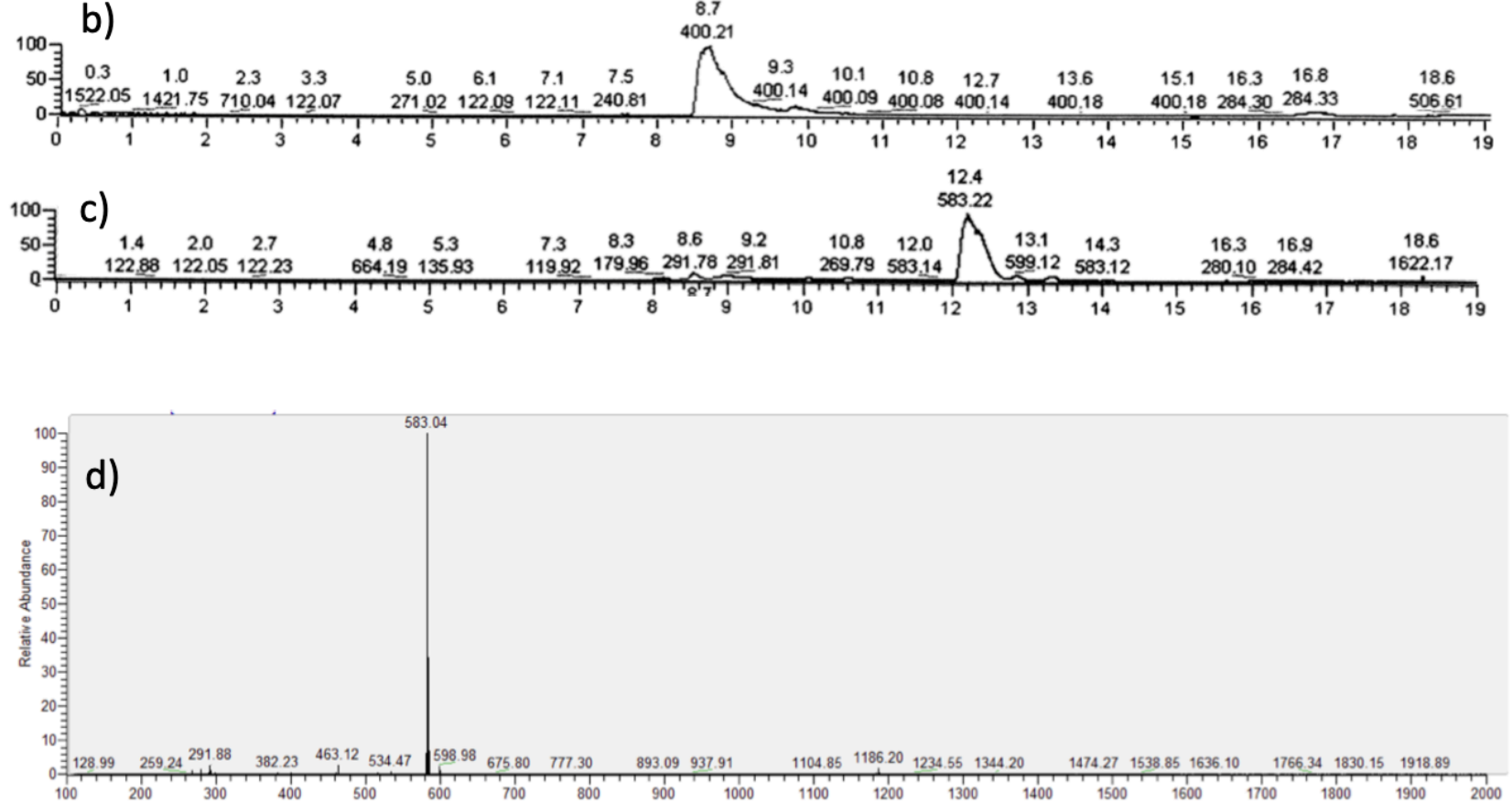

Figure S1. Chromatogram of aminoferrocene (A), difloxacin (B) and DF-Fc conjugate after synthesis,

A)<smiles>CCN1CCN(c2cc3c(cc2F)c(=O)c(C(=O)O)cn3C2CC2)CC1</smiles>

B)<smiles>CC1CCc2cc(F)cc3c(=O)c(C(=O)O)cn1c23</smiles>

C)<smiles>CCn1cc(C(=O)O)c(=O)c2cnc(N3CCNCC3)nc21</smiles>

Figure S2. Structure of enrofloxacin (A), flumequine (B) and pipemidic acid (C). 